\title{
Invertebrate dynamics during the decomposition of dry and fresh willow leaves in Oued Zegzel (Eastern Morocco)
}

\author{
B. Legssyer ${ }^{1}$, H. Chergui ${ }^{2}$, A. Maamri ${ }^{*}$ \\ ${ }^{1}$ Laboratoire d'Hydrobiologie \& Ecologie générale, Faculté des Sciences, Oujda, Morocco ; ${ }^{2}$ Hydrobiologie et Ecologie Générale, Faculté des \\ Sciences Dhar El Mehraz, BP 1796, Fès-Atlas, Morocco
}

\begin{abstract}
Decomposition of dry and fresh willow leaves and the dynamics of invertebrates during this decomposition were followed in upstream and downstream Oued Zegzel, Eastern Morocco. A seasonal comparison of the two studied sites stressed the importance of the structure of the benthic fauna in the process of decomposition. The rate of decomposition was faster in summer, following an increase in the biomass of invertebrates. It was slower in winter, when abundances of Chironomidae reached their maxima. The decomposition of willow leaves was faster upstream, where invertebrates biomass was greater. The artificial drying of leaves before their immersion had a positive effect on the activity of invertebrates. Whereas Melanopsis praemorsa preferred the dry leaves during the four seasons in upstream Zegzel, the preference of Hydropsyche maroccana for the fresh leaves in the downstream station changed according to the season. The seasonal variation of leaves quality seems to especially influence invertebrate colonisation, and thereafter the decomposition process in downstream Zegzel.
\end{abstract}

Keywords : Fresh leaves, dry leaves, seasons, invertebrates, decomposition.

\section{Introduction}

Several studies (Hanlon 1982, Hildrew et al. 1984, Chergui \& Pattee 1988, Maamri et al. 1995, 1997a) showed that invertebrates play a very important role in the energy transfer from terrestrial environments towards the aquatic environments. In Oued Zegzel (Eastern Morocco), Maamri et al. (1995) noted a clear relationship over space and time between the abundance of allochthonous particulate organic matter and the biomass of the main trophic groups of invertebrates (shredders, filterer-collectors and gathering-collectors). In addition to their action of fragmentation, the invertebrates accelerate the process of decomposition

\footnotetext{
*Corresponding author : maamri@sciences.univ-oujda.ac.ma
}

by stimulating the activity and the growth of micro-organisms colonising organic matter (Mason 1976). In fact, in the first stages of decomposition, detritivores or shredders only exploit a small energy fraction of the organic matter since 80 to $90 \%$ are left in the environment in the form of faeces (Chergui \& Pattee 1992). These faeces as well as the fine particles produced represent at the same time a substratum and a nutritive source of organic matter for the micro-organisms. After the leaching of the toxic phenolic substances, the micro-organisms colonise the leaves and while increasing their biomass, represent, with the conditioned leaves, a new more appreciatable nutritive source for the invertebrates (Findlay et al. 1984, 1986, Harrison 1989). Thus the role of invertebrates in the decomposition of organic matter in aquatic environments must not be neglected.

In this study, we followed the seasonal and space dynamics (biomass and density) of invertebrates related to willow leaf decomposition in two sites that differed by their physico-chemical and biological characteris- 
tics. These dynamics were compared in the case of dry and fresh leaves during the four seasons in order to explain the difference observed in the rate of decomposition of dead leaves in Oued Zegzel in Morocco.

\section{Material and methods}

\section{Sampling sites}

The study was performed in Oued Zegzel, a tributary of the Lower Moulouya, in the North-East of Morocco. We chose two stations, one upstream station called S-W Branch and one downstream station called Lower Zegzel. A detailed description of these two stations was given by Maamri et al. (2001).

\section{Preparation of the leaves}

Willow (Salix pedicellata) grows on the banks of Oued Zegzel. Its leaves are deciduous, relatively tender and broad. It provides a great part of the allochthonous particulate organic matter which arrives in the ecosystem (Maamri et al. 1994). Senescent leaves were collected at the beginning of each season of the year 1992-1993. Then they were separed in two groups : leaves preserved at $4^{\circ} \mathrm{C}$ after being were collected, hereafter called fresh leaves, and leaves that were dried at $40^{\circ} \mathrm{C}$ during $48 \mathrm{hrs}$, hereafter called dried leaves.

The batches of each category of leaves consisted of 4 bags with $2 \mathrm{~mm}$ meshes, altogether containing 60 leaves of known initial weight (dry or fresh). One bag (30 leaves) was preserved for studying micro-organism dynamics (Chergui \& Legssyer 1995) whereas the three others (containing 10 leaves each) were used for the study of leaf decomposition. The bags were marked and deposited in both stations at the beginning of each season (March, June, September, December). The total initial fresh weight of batches was corrected by a relationship between fresh and dry weight evaluated at each season as given by Maamri et al. (1997b).

The fauna of the four bags was sorted and identified, then counted and dried at $110^{\circ} \mathrm{C}$ during $24 \mathrm{hrs}$, then weighed in order to determine its biomass in $\mathrm{g}$ (evaluated per g dry weight of leaf batches at each date). The trophic groups of the various taxa was given according to Tachet et al. (1987) (Table I).

\section{Results}

\section{Seasonal and spatial variations in decomposition rate}

The coefficient of exponential decay was estimated by linear regression of ln-transformed values. The

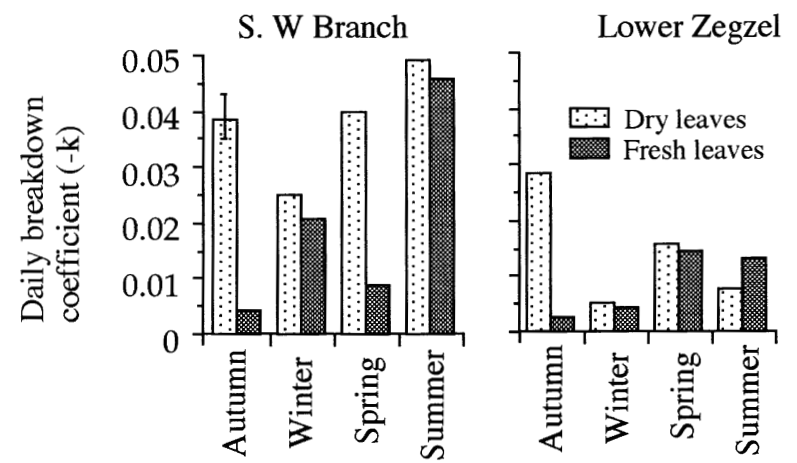

Fig. 1. Daily breakdown coefficients (-k) of dry and fresh Willow leaves at the studied sites during the four seasons (1992). Error bar indicate Standard deviation.

rates of decomposition of willow leaves (both fresh and dried) were faster upstream (Fig. 1). The difference between fresh and dried leaves was also greater there in autumn and in spring. It was smaller in winter and summer. In the Lower Zegzel, this difference was also great in autumn.

\section{Seasonal and spatial variations in the fauna}

The taxonomic richness and the biomass of the invertebrates varied with season, site, and leaf treatment (dried or fresh). Table I lists the taxonomic groups found in the bags.

In the SW Branch, Melanopsis praemorsa and Caenis sp. dominated on the leaves whereas Hydropsyche maroccana and Chironomidae represented the majority of the downstream fauna.

The contribution of each taxonomic group to the total density of the invertebrates varied from one site to the other and according to the seasons. Indeed, in upstream Zegzel, Gasteropoda (Melanopsis praemorsa) dominated during the four seasons with a minimum of $58 \%$ observed on fresh leaves in winter and a maximum of $86 \%$ observed on dry leaves in spring. Ephemeroptera (Caenis sp. and Choroterpes sp.) represented between $7 \%$ (fresh leaves in spring) and $23 \%$ (dried leaves in Autumn) of the fauna collected. The Diptera (Chironomidae) were very few, with a maximum of $19 \%$ observed on the fresh leaves in winter.

In the Lower Zegzel, Diptera (50\%) co-domined with Trichoptera (43\%) in autumn on dried leaves and dominated on fresh leaves (84\%). In winter the Diptera (Chironomidae) represented more than $90 \%$ of the fauna on both types of leaves. In spring, Trichoptera (32\% and $35 \%$ on dry and fresh leaves, respectively) 
co-domined with Ephemeroptera (36\% and $25 \%$ ) and Diptera (29\% and $37 \%$ ). Limnephilidae appeared during this season and were distinctly attracted by the dried leaves (17 individuals, versus 0 on fresh leaves). During the summer the preference of the invertebrates for the fresh leaves was very clear (547 individuals, but only 70 on dried leaves), there were less Chironomidae $(23 \%$ and $32 \%)$, and Ephemeroptera (7\% and $3 \%)$, and a clear predominance of Trichoptera $(67 \%$ and $58 \%$ on the dried and fresh leaves, respectively). During this season Limnephilidae changed their behaviour and were attracted by the fresh leaves (10 and 33 individuals on the dried and fresh leaves, respectively).
In the SW Branch, the fauna collected was dominated by shredders (Fig. 2) who showed two peaks, one in autumn and one in spring.

In the Lower Zegzel, shredders were fewer and prefered dried leaves in autumn and in spring but fresh leaves in summer. Collectors represented by Caenidae and Hydropsychidae dominated in this station during the four seasons. They showed two peaks on dried leaves : one in autumn and the other in spring. On the fresh leaves, the density of collectors increased linearly to reach its peak in summer. Among theses collectors, Chironomidae showed a clear peak in winter.

Table I. Abundance of the various taxonomic groups found by season (sum of values by date and by leaves bags) on dried (d) and fresh (f) leaves.

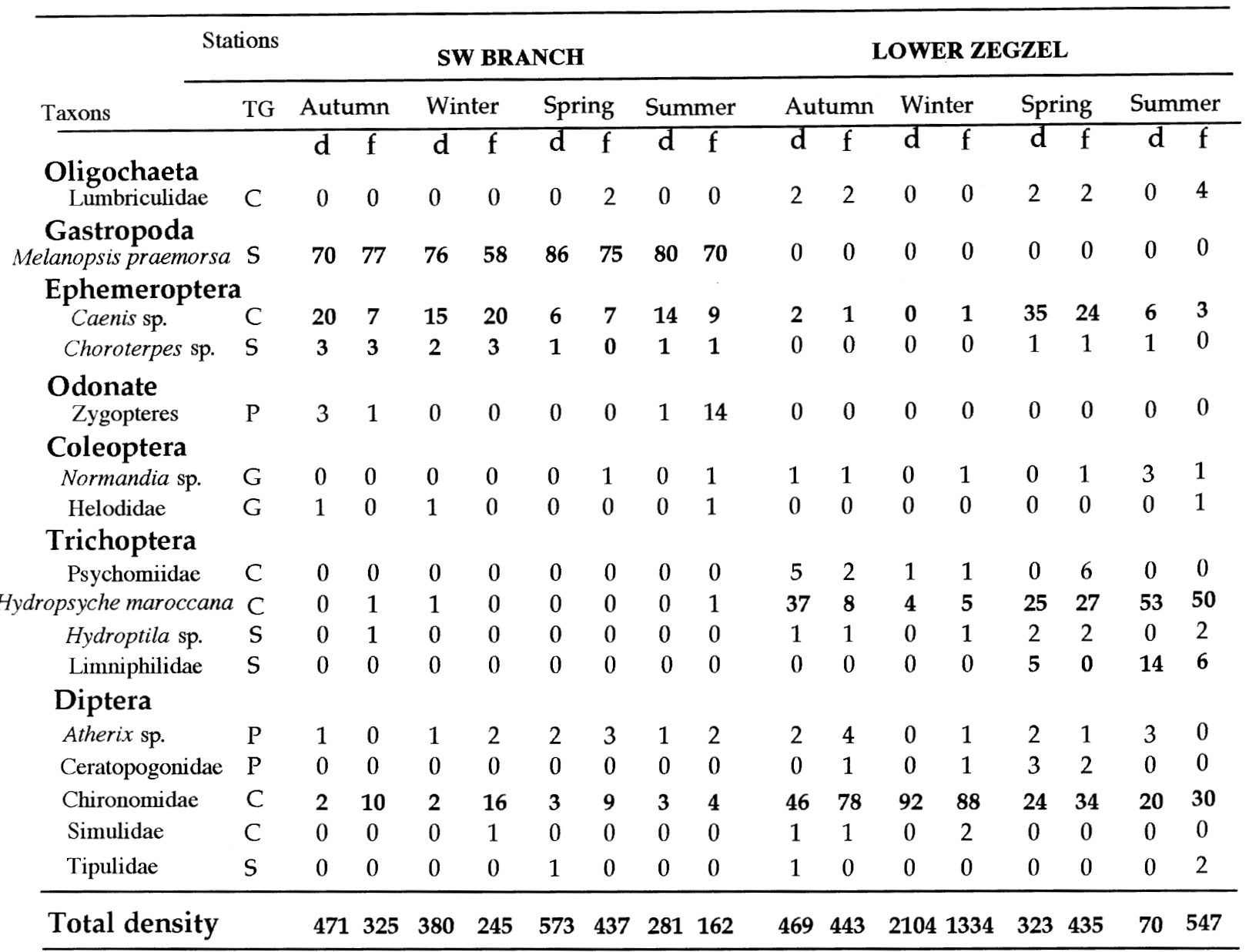

Collectors : C ; Shredders : S ; Predators : P ; Grazers : G ; Trophic groups : TG 
The difference in invertebrate biomass observed in the SW Branch (Fig. 3) between the two categories of leaves is explained by the predominance of Melanopsis praemorsa and Caenis sp. on the dried leaves. This difference was clear during the four seasons. Biomasses and density values did not coincide.

In the Lower Zegzel, maximum invertebrate biomass (Fig. 4) was observed in autumn on dried leaves and in summer on fresh leaves. The biomass of invertebrates was significant on the dried leaves in autumn and winter and on the fresh leaves in spring and summer $(\mathrm{p}<0.05)$. There was a positive correlation between the biomass of invertebrates and the density of Hydropsyche maroccana $(\mathrm{p}<0.05)$. The preferences of Hydropsyche maroccana changed with the season.
They were attracted by the dried leaves in autumn and winter and by the fresh leaves in spring and summer. Caenidae were most numerous in spring

\section{Discussion}

Willow leaf decomposition was rapid in upstream Zegzel and slower downstream. In fact, the predominance of the shredders at the upstream station explains the high values. The slower decomposition downstream was presumably due to the scarcity of shredders.

In addition it was noticed that the rate of decomposition was slower in winter and faster in summer at both stations. This shows the importance of temperature in
S. W Branch

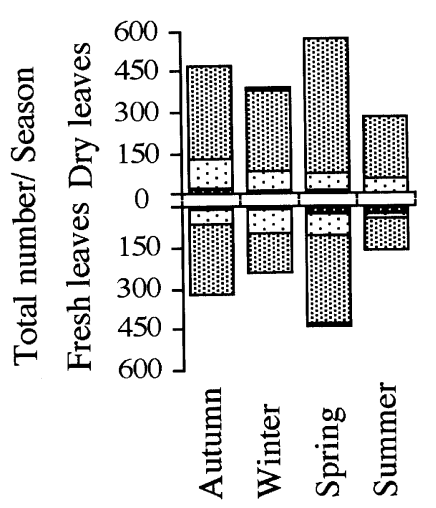

Lower Zegzel

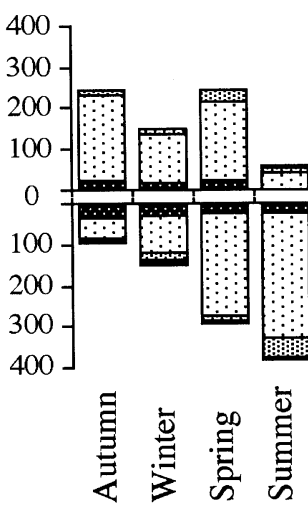

Lower Zegzel

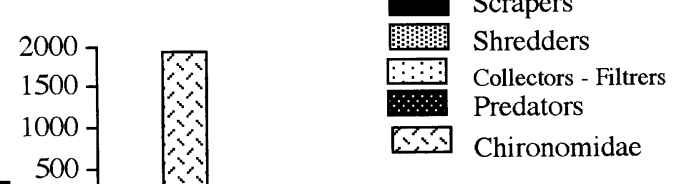

Fig. 2. Spatial and seasonal variations in the density of the main trophic groups found on dried and fresh willow decaying leaves.

\section{S. W Branch}
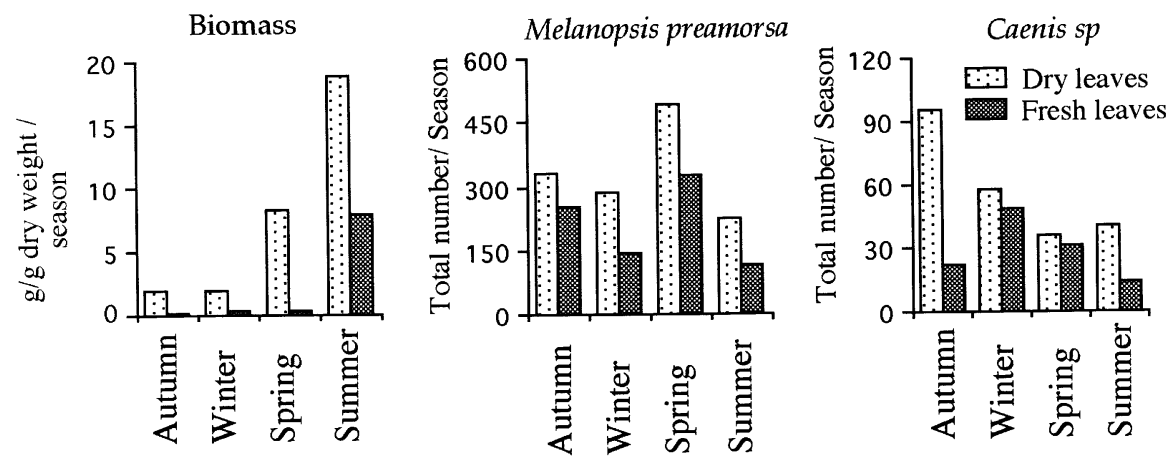

Fig. 3. Seasonal dynamics of total invertebrate, Melanopsis praemorsa and Caenis sp. biomass on the dry and fresh willow leaves in SW Branch (1992). 
the process of decomposition (Suberkropp et al. 1975, Peters et al. 1987, Maamri et al. 1998, 1999). Temperature acts by increasing the activity of the micro-organisms and consequently that of the invertebrates.

In upstream Zegzel, Melanopsis praemorsa dominated and showed an autumnal peak and another more significant one in spring. The seasonal dynamics of these shredders coincides with the allochthonous input of coarse organic matter in November and April (Maamri et al. 1994). In autumn and in spring, the individuals of Melanopsis praemorsa were more numerous but small, whereas in summer they were fewer but larger. This explains the differences observed between the densities and the biomasses. Maamri et al. (1995) and Maamri (2000) made the same observations. The dependence of invertebrates activity upon that of the micro-organisms is quite clear in this station where the invertebrates prefered dried leaves colonised by micro-organisms. The presence of this group is highlighted by the cellulolytic and hydrolytic activity (Chergui \& Legssyer 1995). The behaviour of Melanopsis praemorsa as a shredder who shows automn and spring peaks is controlled by the food value of leaves while basing itself on the nature of the colonising microbial groups. Autumn is characterised by a great fall of willow leaves (Maamri et al. 1994) and by a predominance of aquatic hyphomycetes which are very much related to the allochthonous input of organic matter (Chergui 1990). This was confirmed by the seasonal cellulolytic and hydrolytic activities which reached their maximum on dried leaves in autumn (Chergui \&
Legssyer 1995). Artificial drying influences the rate of decomposition by accelerating the dissolution of soluble substances (Gessner 1991) owing to a disruption of the membrane structure of the cell walls (Harrison \& Mann 1975, Rogers \& Breen 1982). The substances retained by the fresh leaves (phenolic compounds) have an antifungal action and thus delay the attack of the leaves by the micro-organisms, especially aquatic hyphomycetes (Bärlocher, 1990).

Gessner \& Dobson (1993) on one hand, and Chergui $\&$ Pattee (1993) on the other hand found that artificial drying did not influence the colonisation of alder ( $\mathrm{Al}$ nus glutinosa) or willow (Salix sp.) leaves by invertebrates. These differences may be due to the nature of the substrates used. In this study we used bags with fine meshes $(2 \mathrm{~mm})$ inside which only fauna directly related to the leaves could penetrate. Conversely, Gessner \& Dobson (1993) used bags with large meshes (9 $\mathrm{mm}$ ) and Chergui \& Pattee (1993), used leaf packs ; the fauna collected then included as well invertebrates strictly related to the leaves as those using the bags or the packs as a support.

In downstream Zegzel, the collectors represented by Chironomidae, Caenis sp. and Hydropsyche maroccana dominated and showed seasonal fluctuations. In Autumn, Chironomidae co-dominated with Hydropsyche maroccana, whereas in winter they showed a total predominance. This winter abundance coincides with the maximum of bacterial activity (Legssyer 1993). Bacteria and Chironomidae are attracted by fine particulate organic matter (FPOM) and dissolved

\section{Lower Zegzel}

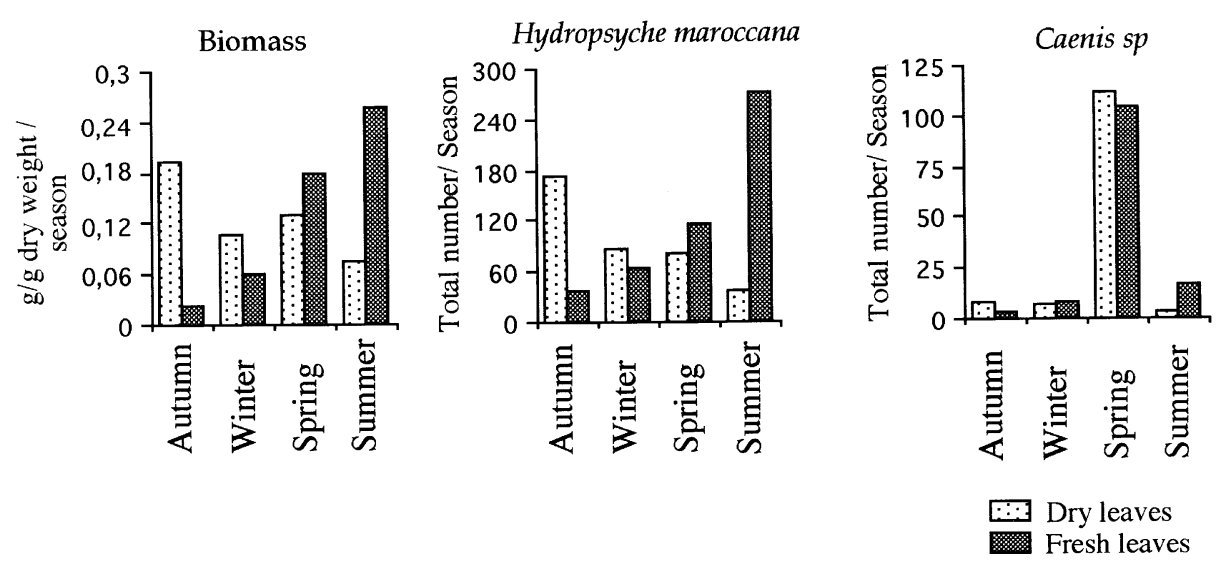

Fig. 4. Seasonal dynamics of total invertebrate, Hydropsyche maroccana and Caenis sp. biomass on the dry and fresh willow leaves in the Lower Zegzel (1992). 
organic matter (DOM) which arrived from upstream Zegzel and which showed a winter peak (February) during the flood period (Maamri et al. 1996). In the same way, Goulder (1986) described a connection between winter abundance of bacteria related to particles and the abundance of suspended organic matter on one hand, and with flow on the other in the two rivers they studied (Yorshire Ouse and Yorshire Derwent).

Following the classification of Tachet et al. (1987), shredders in the downstream station were represented only by Limnephilidae, Tipulidae and Hydroptilidae. So, how can we explain the maximum decomposition rate observed in autumn on dried leaves in the presence of a very low number of these shredders (12 individuals only)? We believe that Hydropsyche maroccana would be better classified as both a shredder and a filterer. In fact, Chergui \& Pattee (1991) reached the same conclusion following an experimental study : they found that the dried leaves of willow and oleander incubated in the presence of Hydropsyche maroccana lost $13 \%$ and $8 \%$ of their initial weight, respectively, in 30 days. In summer, Trichoptera dominated in the absence of any trophic competition. The shredders represented by Hydroptilidae and Limnephilidae were attracted by the fresh leaves, which coincides with the actual values of biomass on the one hand and the acceleration of decomposition rate on the other. In the same way, Hydropsyche maroccana proved to be very much attracted by fresh leaves (271 individuals found against only 37 on dried leaves).

In the Lower Zegzel, the relationship between micro-organisms and invertebrates was very clear in autumn on dried leaves and in summer on fresh leaves. Dried autumnal leaves disappeared faster following an intense hydrolytic activity of micro-organisms (Chergui \& Legssyer 1995) and a massive attack by invertebrates. In summer, invertebrates were attracted by fresh leaves in which was detected a maximum of deshydrogenasic activity (Chergui \& Legssyer 1995) that influences the rate of decomposition. However it is thought that the micro-organisms which prefer dried leaves in autumn are different from those that prefer the fresh leaves in summer.

The dependence of invertebrates activity on that of aquatic hyphomycetes was shown by Chergui \& Pattee (1991) who found that the percentage of assimilation by Melanopsis praemorsa was greater when willow leaves were conditioned by Lemonniera aquatica. The percentage of assimilation was very low in the presence of Tetracladium marchalianum. In addition, Arsuffi \& Suberkropp $(1984,1985)$ showed that the invertebrates select the leaves of high food value while basing themselves on the identity of the colonizing aquatic hyphomycetes.

In the same way, by comparing the rate of decomposition of poplar leaves between the autumn/winter and the spring/summer seasons, Garden \& Davies (1988), found that the leaves disappeared faster in the former than in the latter. The slower decomposition during the spring/summer season seemed to be related to a reduction in the microbial activity and biomass. These authors think that the microbial flora which colonises the leaves in spring/summer is less attractive for invertebrates. During our study, the micro-organisms which conditioned the leaves in summer were presumably more attractive than those which colonized them during the other seasons. This microbial group showed a preference for the fresh leaves.

\section{Conclusion}

The fungal component seems to play the crucial role in decomposition by its enzymatic ability which makes the leaves more assimilable by shredders. In contrast, the bacterial biomass appears more directly profitable for the filterers and collectors.

However our knowledge of the dynamics and structure of microbial communities in Oued Zegzel, essentially bacterial and protozoan groups, is insufficient for explaining the seasonal variability of invertebrate behaviour towards the leaves.

\section{References}

Arsuffi L.T. \& Suberkropp K. 1984. — Leaf processing capabilities of aquatic hyphomycetes : interspesific differences and influence on shredder feeding preferences. Oikos, 42, 144-154.

Arsuffi L.T. \& Suberkropp K. 1985. - Selective feeding by stream caddisfly (Trichoptera) detritivores on leaves with fungal colonized patches. Oikos , 45, 50-58.

Baker J.H. \& Bradnam L.A. 1976. - The role of bacteria in the nutrition of aquatic detritivores. Oecologia, 24, 95-104.

Bärlocher F. 1990. - Factors that delay colonization of fresh alder leaves by aquatic hyphomycetes. Arch. Hydrobiol., 119 (3), 249-255.

Bärlocher F. 1991. - Fungal colonization of fresh and dried leaves in the River Teign (Devon, England). Nova Hedwigia, 52, 349-357.

Blum L.K., Mills A.L., Zieman J.C. \& Zieman R.T. 1988. — Abundance of bacteria and fungi in seagrass and mangrove detritus. Marine Ecology Progress Series, 42, 73-78.

Bunn S.E. 1988. - Processing of leaf litter in a northen Jarrah stream, Western Australia. II, The role of macroinvertebrates and the influence of soluble polyphenols and inorganic sediment. $\mathrm{Hy}$ drobiologia, 162, 211-223.

Chergui H. \& Legssyer B. 1995. — Variation de l'activité des microorganismes au cours de la décomposition des feuilles de Salix pedicellata dans le réseau de la Basse Moulouya, Maroc oriental. Ann. Limnol., 30, 323-332. 
Chergui H. \& Pattee E. 1988. - The impact of benthic invertebrates on the breakdown of poplar leaves in the network of a large European river. Arch. Hydrobiol., 113 (1), 15-25.

Chergui H. \& Pattee E. 1991. - An experimental study of the breakdown of submerged leaves by hyphomycetes and invertebrates in Morocco. Freshwat. Biol., 26, 97-110.

Chergui H. \& Pattee E. 1992. - Processing of fresh and dry Salix leaves in a Moroccan river system. Acta Oecologica, 13 (3), 291-298.

Chergui H. \& Pattee e. 1993. - Fungal and invertebrate colonization of Salix fresh and dry leaves in a Moroccan river system. Arch. Hydrobiol., 127 (1), 57-72.

Cummins K.W. \& Klug M.J. 1979. - Feeding ecology of stream invertebrates. Ann. Rev. Ecol. System., 10, 147-172.

Findlay S.E., Meyer J.L. \& Smith P.J. - 1984. Significance of bacterial biomass in the nutrition of a freshwater isopod (Lirceus sp.) Oecologia, 63, 38-42.

Findlay S.E., Meyer J.L. \& Smith P.J. 1986. - Contribution of fungal biomass to the diet of a freshwater Isopod (Lirceus sp.). Freshwat. Biol., 16, 377-385.

Garden A. \& Davies R.W. 1988. - Decay rates of autumn and spring leaf litter in a stream and effects on growth of a detritivore. Freshwat. Biol., 19, 297-303.

Gessner M.O. 1991. — Differences in processing dynamics of fresh and dried leaf litter in a stream ecosystem. Freshwat. Biol., 26, 387-398.

Gessner M.O. \& Dobson M. 1993. - Colonization of fresh and dried leaf litter by lotic macroinvertebrates. Arch. Hydrobiol., 127 (2), 141-149.

Goulder R. 1986. - Seasonal variation in the abundance and heterotrophic activity of suspended bacteria in two lowland rivers Freshwat. Biol., 16, 21-37.

Hanlon R.D.G. 1982. - The breakdown and decomposition of allochthonous and autochthonous plant litter in an oligotrophic lake (Llyn Frongoch). Hydrobiologia, 88, 281-288.

Harrison P.J. 1989. — Detrital processing in seagrass systems, a review of factors affecting decay rates, remineralization and detritivory. Aquatic Botany, 23, 263-288.

Harrison P.J. \& Mann K.H. 1975. - Detritus formation from eelgrass (Zostera marina L.) : The relative effects of fragmentation, leaching and decay. Limnol. Oceanogr., 20, 924-934.

Hildrew A.G., Towsend C.R., Francis J. \& Finch K. 1984. - Cellulolytic decomposition in streams of contrasting $\mathrm{pH}$ and its relationship with invertebrate community structure. Freshwat. Biol., 14, 323-328.

Iversen T.M. 1973. - Decomposition of autumn-shed leaves in a springbrook and its significance for the fauna. Arch. Hydrobiol.,, 72, 305-312.

Kostalos M. \& Seymour R.L. 1976. — Role of microbial enriched detritus in the nutrition of Gammarus minus (Amphipoda). Oikos, 27, 512-516.

Legssyer B. 1993. - Evolution de l'activité des micro-organismes et des invertébrés durant la décomposition des feuilles du Saule dans le réseau de la Basse Moulouya. PhD Thesis, Faculté des Sciences, Oujda. $157 \mathrm{p}$

Maamri A. 2000. - A critical comparison of techniques for estimating bacterial abundance on leaf litter. Ann. Limnol., 36 235-239.

Maamri A., Bärlocher F., Pattee E. \& Chergui H. 2001. — Fungal and bacterial colonisation of Salix pedicellata leaves decaying in permanent and intermittent streams in Eastern Morocco. Internat. Rev. Hydrobiol., 86, 337-348.
Maamri A., Chauvet E., Chergui H., Gourbière F. \& Pattee E. 1998. - Micro-organism dynamics on dead leaves in a temporary Moroccan river, I- Fungi. Arch. Hydrobiol., 144, 41-59.

Maamri A., Chergui H. \& Pattee E. 1994. - Allochthonous input of coarse particulate organic matter to a Moroccan mountain stream. Acta Oecol., 15, 495-508.

Maamri A., Chergui H. \& Pattee E. 1995. — Impact des apports végétaux allochtones sur la distribution de la faune benthique dans un cours d'eau montagnard marocain, l'oued Zegzel. Ecologie, 26, 81-94.

Maamri A., Chergui H. \& Pattee E. 1996. — Dynamics of fine particulate and dissolved organic matter in a moroccan mountain stream, effects of stream flow and litter quality. Pol. Arch. Hydrobiol., 43, 401-410.

Maamri A., Chergui H. \& Pattee E. 1997 a. — Dynamique des apports de litière végétale et de la faune invertébrée dans une rivière méditerranéenne temporaire, l'oued Cherraa, au Maroc. Ecologie, 28, 251-264.

Maamri A., Chergui H. \& Pattee E. 1997 b. — Leaf processing in a temporary northeastern Moroccan river. Arch. Hydrobiol., 140, 513-531.

Maamri A., Pattee E., Gayte X. \& Chergui H. 1999. - Micro-organism dynamics on dead leaves in a temporary Moroccan river, IIBacteria. Arch. Hydrobiol., 144, 157-175.

Mason C.F. 1976. - Relative importance of fungi and bacteria in the decomposition of Phragmites leaves. Hydrobiologia, 51 65-69.

Minshall G.W. 1967. — Role of allochthonous detritus in the trophic structure of a woodland spring brook community. Ecology, 48, 139-149.

Newel S.Y. 1981. - Fungi and bacteria in or on leaves of eelgrass (Zostera marina L) from Chesapeake Bay. Appl. Environ. Microbiol., 41, 1219-1224.

Peter G.T., Webster J.R. \& Benfield E.F. 1987. — Microbial activity associated with seston in headwater streams : effects of nitrogen, phosphorus and temperature. Freshwat. Biol., 18, 405-413.

Petersen R.C. \& Cummins K.W. 1974. — Leaf pack processing in a woodland stream. Freshwat. Biol., 4, 343-368.

Rogers K.H, \& Breen C.M. 1982. - Decomposition of Potamogeton cripsus $\mathrm{L}$. : The effects of drying on the patterns of mass and nutrient loss. Aquatic Botany, 12, 1-12.

Sinsabaugh R.L., Linkins A.E. \& Benfield E.F. 1985. - Cellulose digestion and assimilation by three leaf-shredding aquatic insects. Ecology, 66, 1464-1471.

Suberkropp K., Arsuffi L.T. \& Anderson J.P. 1983. — Comparison of degradative ability, enzymatic activity and palatability of aquatic hyphomycetes grown on leaf litter. App. Environ. Microbiol., 46, 237-244.

Suberkropp K. \& Klug M.J. 1976.- Fungi and bacteria associated with leaves during processing in a woodland stream. Ecology, 57, 707-719.

Suberkropp K. \& Klug M.J. 1981. — Degradation of leaf litter by aquatic hyphomycetes. Pages 761-776 in The fungal community, $1^{\text {st }}$ Ed. Wicklow D.T. \& Carroll G.C. Deckker, New York.

Suberkropp K., Klug M.J. \& Cummins K.W. 1975. — Community processing of leaf litter in woodland stream. Verh. Internat. Ve rein. Limnol., 19, 1653-1658.

Tachet H., Bournaud M. \& Richoux PH. 1987. — Introduction à l'Ètude des macroinvertébrés des eaux douces. Association Française de Limnologie, Univ. Lyon I. 156 p.

Webster J. \& Towfik F.H. 1972. - Sporulation of aquatic hyphomycetes in relation to aeration. Trans. Br. Mycol. Soc., 59, 353-364. 